\title{
Investigating Quality Perceptions of International Services by Chinese Consumers
}

\author{
Subir Bandyopadhyay \\ Professor of Marketing \\ Indiana University Northwest \\ School of Business \& Economics \\ 3400 Broadway, Gary, IN 46408 \\ Phone No: (219) 980-6900 \\ Email: sbandyop@iun.edu
}

Please send all correspondence to the first author at the above address. We thank Aishariya Bandyopadhyay, Chung Dong, Sabena Sriplo, and Datianna Tillman for data collection and background research. The author gratefully acknowledges the financial support from the School of Business \& Economics of Indiana University Northwest, the Center for Urban and Regional Excellence of Indiana University Northwest, and the Byron Root Foundation. 


\title{
Investigating Quality Perceptions of Foreign Services by Chinese Consumers
}

\begin{abstract}
Consumers are known to use the country-of-origin $(\mathrm{COO})$ of a product to infer the quality of products. Products of technologically advanced countries such as the US and Germany are known to enjoy positive country-of-origin effects. Conversely, products made in the developing countries typically suffer from negative $\mathrm{COO}$ effect. While this influence of $\mathrm{COO}$ is widely recognized for products, the same cannot be said about services. Only a handful of studies have empirically investigated the relationship between $\mathrm{COO}$ and perceived service quality. Additionally, most of these studies in this research paradigm, are undertaken in developed markets; hence their findings cannot be extrapolated to the newly industrialized countries (NIC) that offer tremendous market potential for global services. It has, therefore, become imperative for multinational companies to understand if and how consumers in the major NICs use $\mathrm{COO}$ and other cues to infer service quality. This insight is critical in developing effective pricing and promotion strategies for these markets.

Using data collected from consumers in Beijing in the Peoples Republic of China, we demonstrate significant COO effect on two service categories: hotels and restaurants. We also highlight how these research findings will help managerial decisions about pricing and promotion.
\end{abstract}

Key words: Cross-cultural consumer behavior; Chinese consumers; Country-of-origin effects; Perceived service quality. 


\section{Introduction}

Country-of-Origin (in short, $\mathrm{COO}$ ) is a topic that has been heavily researched due to the importance of understanding why consumers perceive products and services the way they do. In general, products made in developed countries enjoy a positive $\mathrm{COO}$ effect. For example, automobiles made in Germany, consumer electronics from Japan, and computers from the US enjoy positive COO effect universally (Gallup, 1991). Conversely, products made in developing countries typically suffer from a negative COO effect (Ettenson and Klein, 2005). The extant literature on COO effects clearly shows an influence of $\mathrm{COO}$ on product evaluation. (See Bandyopadhyay and Banerjee, 2002, Bandyopadhyay, Wongtoda, and Rice, 2011, Wongtoda, Rice and Bandyopadhyay, 2012). This influence is stronger in single-cue studies as compared to multiple-cue studies. The $\mathrm{COO}$ effect on product evaluation is found to be weaker in the presence of other important cues such as warranty (Thorelli, Lim and Ye 1989), and price and retail distribution (Chao 1989). Similarly, Chao (1993) has demonstrated that the $\mathrm{COO}$ effect may have two different dimensions: country-of-design (COD) and country-of-assembly (COA). Unfortunately, few of these studies investigate the $\mathrm{COO}$ effect from the perspective of a consumer in a developing country. Notable exceptions are Bandyopadhyay and Banerjee, 2002, and Bandyopadhyay and Dong, 1995.

Unlike $\mathrm{COO}$ for products, very few studies have tried to find out what effect $\mathrm{COO}$ has on consumers choosing a service. Notable exceptions are Bandyopadhyay and Pardasani (2011), Pardasani and Bandyopadhyay (2014), Ahmed, Johnson, Ling, Fang, and Hui, (2002) and Prabhakaran, Raj, and Rajagopal, (2008). As important as it is to know American consumers' buying habits of services, it is very important to research the buying habits of foreign consumers as well.

This is a very important topic to research because understanding how consumers choose services in foreign markets could lead to substantial profits for a multinational company. Based on a 
thorough review of the COO literature on services, Javalgi, Cutler and Winans (2001) conclude that COO cues are highly important in the evaluations of services, particularly when brand names are not well known to the consumer. Many companies realize this, and have gone to great efforts to evaluate and keep records of service quality levels (Upal, 2008; Hauser and Clausing, 1988). By offering high levels of service quality, the Hospital Corporation of America has benefitted in terms of higher returns on investments and higher profits (Koska, 1990). Further rewards can come in the form of increased market shares (Buzzel \& Gayle, 1987), and competitive advantage (Thi Bui \& Nguyen, 2012).

The United States has a substantial manufacturing deficit but a trade surplus in service sector (Cateora, Gilly and Graham, 2012). American businesses need to realize the competitive advantages that they have in the service sector, and capitalize upon them. It is imperative to take advantage of this situation, especially since many American jobs are being outsourced to counties overseas. In 2013, more than 2.6 million U.S. jobs were outsourced (Job Outsourcing Statistics 2014). Our study is expected to fill these important gaps in the $\mathrm{COO}$ and cross-cultural service quality literature.

This paper will first provide a brief review of the literature on the COO effect on services and the impact $\mathrm{COO}$ has on Chinese consumers' perception of service quality. We will then discuss our research hypothesis, followed by the description of methodology and results of our empirical study. We will conclude with a brief description on the limitations of the study and the scope of future research in this area.

\section{Literature Review}

There are only a few experimental studies that focus on the effects of the $\mathrm{COO}$ on services. As a result, only a handful of new theories and hypotheses could be derived from the outcome of those empirical studies. It is believed that $\mathrm{COO}$ is an attribute that consumers use to make inferences about a service or a service provider's quality (Maheswaran, 1994). When the COO is presented in addition 
to other service attributes, consumers understand the additional information as a true attribute of the provided service. Country-of-Origin has a direct influence on the service provider's attributes, which in turn affects service evaluations, and the COO effect may also result in perceptions of the general quality of a service provider from a particular country. This new "attribute" can be used to bolster the service provider's quality of service. When service evaluations are dependent on performance characteristics, the COO may have a greater influence on decision making (Johansson et al., 1985). Kaynak and Cavusgil (1983) suggest that COO can function as a surrogate variable, having greater impact when little else is known about the service provider.

There is some evidence that the COO is concealed in order to prevent loss of customers. People tend to rank the performance of a service from a developing country as inferior to others already established in the market (Khanna, 1986). Countries are stereotyped based on their level of development (developed vs. developing) but not based on the quality of a service (Rao, 2012). There is also empirical evidence that African Americans and Asians hold higher service quality expectations for professional services, whereas the service quality expectations held by Anglos and Hispanics are mixed (Webster, 1989). The general hypothesis developed from these arguments is as follows: service provider's selection is dependent upon a three-way interaction involving service provider nationality, level of information, and consumer nationality. There is a common tendency for consumers in developing countries to perceive companies from developed countries provide better services better than those from their home countries (Rao, 2012).

In order to understand why consumers react to the $\mathrm{COO}$ effect, the service providers must grasp two critical points: trust and ethical perceptions (Swan et al., 1985). Trust is defined as both an emotional and cognitive state in which an individual relies on information received from another person (Swan et al., 1985). Trust is built through superior quality, reliability, and a consistent favorable outcome of the service. Once trust is built and maintained, the consumer will continue to rely on the 
service being provided. A study done by Nielsen in 2013 showed that most people trust their friends and family (word-of mouth) when it comes to buying something (Newswire 2013). This is significant because once trust is gained from one consumer it will be easier to gain the same trust from someone they know.

The service provider must also understand ethical perceptions of a nationality or people. Ethical perceptions are defined as the degree to which another individual is perceived to be practicing moral and community standards in interpersonal relationships. The recognition that the other party in an exchange situation lacks an ethical orientation may lead to a reduction or suspension of existing or future business between the two (Pruden, 1971). Therefore, customers will begin and continue to purchase a service if it is thought to be moral and ethical.

Researchers have various suggestions for uses of service quality measurement instruments. Some researchers recommend using service quality instruments in order to identify problems, determine how to correct these problems, and evaluate the improvements (Kettinger and Lee, 1995). Others believe that companies should use quality surveys to warn of possible problems that could lead to departing customers (Zeithaml, Berry and Parasuraman, 1996). Parasuraman, Zaithaml and Berry (1988) developed a new scale SERVQUAL to measure service quality. According to SERVQUAL, five important aspects of service quality are: 1. Reliability, 2. Assurance, 3. Tangibles, 4. Empathy, and 5. Responsiveness. Reliability refers to whether the promised service is performed dependably and accurately; responsiveness refers to the willingness or readiness to help customers and provide prompt service; assurance refers to knowledge and courtesy of employees and their ability to inspire trust and confidence; empathy refers to caring, individualized attention the firm provides its customers, and tangibles refers to physical facilities, equipment, decor, etc.

There are a few studies that explored different components of service. Maisters (1985) explored the consumer perception of waiting time. During the period of one week, he asked 50 hotel customers 
and 50 customers using a restaurant to express their level of agreement with 15 statements on a 5-point scale. More than $70 \%$ of all respondents were clearly concerned about waiting times. There were no significant differences in the views of hotel and restaurant customers for 11 of the statements. Those with a significant difference were hotel guests who believed more strongly that quality is worth waiting for, and they were generally more willing to pay more to avoid queuing. The results of the survey indicated that waiting does affect the mood of the customer and the propensity to spend. The survey results also suggest that there comes a point where an unacceptable wait begins to affect customers' perception of quality.

Several researchers have explored the relative importance of the factors of tourism. For example, Choi and Chu (2001) found that courtesy, respect and politeness, responsiveness to customers, and prompt services to customers in areas of booking and room service are the most important factors in determining service quality for a hotel. In terms of importance, travelers surveyed by Anath et al (1992) have identified "price and quality" as the most important attribute, followed by "security" and "convenience of location". The findings reported by Wong et al. (1999) indicated that employee related dimensions (i.e. behavior and appearance) are more significant than the tangibles and reliability dimensions of hotel attributes.

Prabakaran, Raj, and Rajagopal (2008) used the SERQUAL model to determine perceived service quality for tourism services in Kerala, India. The data was collected from 100 tourists, where 50 of whom were from foreign countries who had visited in various tourist places. The data were collected by administering the questionnaire based on the SERVQUAL model using six major dimensions; tangibility, responsiveness, reliability, service product, assurance, and service responsibility. They found that the tangibility dimension of SERVQUAL influences domestic 
tourists while the responsiveness dimension of service quality influences the foreign tourists. Other dimensions of service quality were not found significant.

Ahmed et al. (2002) examined COO and brand effects on consumer's attitudes, quality perceptions, and purchase intentions in regards to international cruise line packages in Singapore. A pre-test was conducted which asked 20 cruise-line passengers to rate cruise packages and their perception of quality from six countries (US, UK, Norway, Greece, Singapore, Malaysia). Malaysia scored the lowest and the U.S. scored the highest. Two major cruise-lines were analyzed: Royal Caribbean Lines and Star Cruises in the USA and Malaysia respectively.

The actual survey was conducted in Singapore where 192 respondents took part. 52\% of the respondents were Singaporeans and 48\% foreigners. Results indicated that Singaporeans (locals) were more likely than foreigners to use $\mathrm{COO}$ as an attribute in their decision of a cruise line. Also, those who cruise once a year or more tend to rely less on $\mathrm{COO}$ information in cruise line purchase decisions, while for less frequent cruise line travelers, $\mathrm{COO}$ is an important attribute when making a purchase decision. According to Ahmed et al. (2002), COO appears to have a stronger effect than brand in consumers' evaluations of the quality of cruise products and their attitudes toward the products.

Barring the few studies described above, most of the studies on $\mathrm{COO}$ effect on services are based on the U. S. market. Most of the studies do not look at foreign consumer's preferences, let alone the quality perception of American services by foreign consumers in their native country. Our paper aims to fill this gap in the literature by examining the relative effects of $\mathrm{COO}$ in the global services market on a foreign consumer's choice to pick an American service over her native country's service.

\section{Development of Research Hypotheses}

Several studies have reported negative stereotyping of goods made in the newly industrialized countries (NIC) by American consumers (Khanna, 1986, Johansson and Nebenzhal, 1986, Cordell, 
1992). Bandyopadhyay and Banerjee (2002) empirically demonstrated that Indian consumers perceive that technologically sophisticated products (e.g., camera, color television, and refrigerator) made in an industrialized country are of better quality than those made in a NIC country like India. Similar results are reported by Bandyopadhyay and Dong (1995) for Chinese consumers. We believe that this perception is valid for services as well. Our first hypothesis, therefore, is the following:

H1. The perceived quality of foreign-owned service organizations will be higher than that for local service organizations.

Research has shown that the $\mathrm{COO}$ effect on product and service evaluation is reduced in the presence of other cues. For example, Chao (1989) has shown that price and store image have a mediating role on the effect of $\mathrm{COO}$ on product and service evaluation. In particular, price is found to be have a positive impact on product quality. We expect that the same positive relationship will be valid for services as well. Hence, our second hypothesis is as follows:

H2. Price has a positive relationship with the perceived service quality for both foreign-owned as well as locally-owned service organizations.

The impact of $\mathrm{COO}$ on product evaluation is diminished in presence of other cues such as price (Bandyopadhyay and Banerjee, 2002, Chao 1989), and store image (Chao 1989). For consumers in China, we expect this impact to be more on the local services than foreign (US) services. This is because the local services do not benefit from the positive perception about a service originating from an advanced country such as the U.S. Our third hypothesis is, therefore, as follows:

H3. The influence of price on perceived service quality will be greater for locally-owned service organizations than for foreign-owned service organizations.

\section{Methodology}


Price and country of origin (COO) are manipulated as between-subjects factors in a series of experiments in China. We selected China as the country of study because of the size of its economy, $2^{\text {nd }}$ largest in the World after the US, and its importance in world trade. In order to check for generalizability of results, we have selected two service categories: restaurant and hotel. Three types of restaurants were selected: (1) a US owned multinational chain, (2) a local Chinese company, and (3) a restaurant inside a US owned hotel chain. Similarly, two types of hotels were selected: (1) a US owned multinational chain, and (2) a local Chinese company. Also, two levels of price (high vs. low) were used. Thus, we used a $3 \times 2$ fully factorial design.

The exact prices used were: 200 Yuan (32 Dollars) and 600 Yuan (98 Dollars) for hotels and 50 Yuan (8 Dollars) and 150 Yuan (25 Dollars) for restaurants. The levels of high and low prices for each category were ascertained through a pre-test with a group of 25 participants. We used the same service descriptions as used in the main experiment. We asked the subjects to indicate the typical high and low prices for each service category.

Hotel and restaurant are chosen as the service categories because Chinese consumers are exposed to local- and foreign-owned hotels and restaurants. Thus the lack of service familiarity is not expected to influence service evaluation greatly.

\section{Data Collection}

Data were collected from a random sample of 122 residents in Beijing, the capital city of the People's Republic of China. Feedback from one response was found to be incomplete. Thus, the sample size was reduced to 121. Data were collected in collaboration with two hotels and three restaurants. Respondents were given a questionnaire at the time of checking-in in the hotel. As for restaurant diners, they were requested to complete a questionnaire after they were seated. Only one person from a party of diners was asked to complete the questionnaire. Each respondent was provided with a one-page service profile that included price and place-of-origin information. 
Subjects were asked to rate the quality of hotels and restaurants in five different dimensions: (1) tangibles, (2) reliability, (3) responsiveness, (4) assurance, and (5) empathy. We used a modified version of the SERVQUAL scale first developed by Parasuraman et al. (1988). These dimensions were measured by 3, 4, 3, 4 and 4 item scales respectively. Hence the overall scale had 18 items in total. A sample questionnaire is enclosed in Appendix 1. Every 7-point Likert type scale was anchored by "strongly agree" and "strongly disagree" at either end. This comprehensive scale was developed to delineate the effect of price and type of ownership on several dimensions of service quality. Cronbach alphas for all dimensions were found to be higher than 0.77 thereby validating their reliability.

\section{Results}

Individual items in each quality dimension are found to be highly correlated. Hence ratings on individual scales are averaged. Pairwise comparisons are done to ascertain which pairs of means show significant differences. Results are provided in Table 1 and Table 2 . We provide below the results for each dimension for both service categories: hotel and restaurant.

\section{Tangibles}

(a) Hotel

Results in Table 1 show that ratings for tangibles for foreign hotels and local hotels are not statistically different ( $M=4.29$ vs. $M=3.95$, n.s.). Thus we do not find any support for Hypothesis 1 .

(b) Restaurants

Results in Table 3 indicate are in more expected lines. Both foreign restaurant chains and inhotel restaurants are rated significantly higher than local family restaurants $(M=4.17$ vs. $M=2.68, F$ 29.04 and $\mathrm{M}=4.23$ vs. $\mathrm{M}=2.68, \mathrm{~F}=31.7$ respectively). Hence Hypothesis 1 is supported.

\section{Reliability}


(a) Hotel

Table 1 results indicate that reliability ratings for foreign hotel chains are significantly higher than those for local hotels ( $M=5.60$ vs. $M=4.60, F=9.31)$. Results seem to suggest that foreign chains are more reliable to offer timely service and are more eager to solve customer problems. Thus, this result supports Hypothesis 1.

(b) Restaurant

Similar to hotels, reliability ratings for foreign owned restaurants and in-hotel restaurants are significantly higher than local restaurants $(\mathrm{M}=3.85$ vs. $\mathrm{M}=2.83, \mathrm{~F}=12.79$ and $\mathrm{M}=5.23$ vs. $\mathrm{M}=3.85$, $\mathrm{F}=26.20)$. Hence we find support for Hypothesis 1 .

\section{Responsiveness}

(a) Hotel

Respondents strongly feel that foreign hotel chains are more responsive to customers' needs than local hotels $(\mathrm{M}=3.82$ vs. $\mathrm{M}=2.63, \mathrm{~F}=32.68)$. Results indicate that respondents believe that foreign chains will provide prompt service and are ready to help customers as compared to local hotels. Thus, we find support for Hypothesis 1.

(b) Restaurants

Results are similar for restaurants. Both in-hotel and foreign restaurants are found to be more responsive than local restaurants $(\mathrm{M}=4.4 .5$ vs. $\mathrm{M}=2.83, \mathrm{~F}=68.24$ and $\mathrm{M}=3.85$ vs. $\mathrm{M}=2.83, \mathrm{~F}=16.54$ respectively). Also, in-hotel restaurants are again rated higher than foreign restaurants (M=4.45 vs. $\mathrm{M}=3.63, \mathrm{~F}=17.59)$. Thus Hypothesis 1 is supported.

\section{Assurance}

(a) Hotel 
Assurance captures consumers' confidence on the service provider's ability to provide courteous and proper service to the customers. Here again, foreign hotel chains score significantly higher than the local hotels. Thus, hypothesis 1 is supported.

(b) Restaurant

Results are consistent for restaurants as well. In-hotel restaurants are rated significantly higher than both foreign restaurant chains $(\mathrm{M}=4.35$ vs. $\mathrm{M}=3.87, \mathrm{~F}=7.18)$ and local restaurants $(\mathrm{M}=4.35$ vs. $\mathrm{M}=3.14, \mathrm{~F}=44.87)$.

\section{Analysis of Variance Results:}

Tables 3 and 4 provide the analysis of variance results for five dimensions of perceived service quality. Some of the notable results are as follows:

\section{Hotel}

1. Price has significant influence on all of the five dimensions of perceived service quality except responsiveness. This is consistent with the typical Chinese perception that "better" stores carry "expensive" products.

2. Country of origin (COO) has significant influence on all of the five dimensions of perceived service quality.

3. Price and $\mathrm{COO}$ have significant interactive effect on all dimensions of perceived service quality except tangibles. Figures 1 through 4 show the interaction plots for reliability, responsiveness, assurance and empathy respectively. As expected, the ratings for reliability, assurance and empathy for higher priced local hotels are more than those for lower priced hotels. On the other hand, these ratings for the higher priced foreign hotels are not different from those of lower priced hotels. Thus, we find support for H3. Results for responsiveness, however, do not support H3. Here, the price effects for foreign- 
owned hotels are somewhat more than locally-owned hotels.

4. The duration of stay also has a strong and significant influence on responsiveness and only moderate influence on assurance.

\section{Restaurant}

1. Price significantly influences three dimensions of perceived quality viz. tangibles $\left(F_{1,120}=7.03\right)$, reliability $\left(F_{1,120}=11.72\right)$ and assurance $\left(F_{1,120}=12.24\right)$. However, it does not have any influence on responsiveness and empathy. COO has a strong influence on all five dimensions of perceived quality.

2. Price and $\mathrm{COO}$ have significant interactive influence on tangibles $\left(\mathrm{F}_{2,119}=5.32\right)$, and moderately significant influence on reliability $\left(F_{2,119}=2.85\right)$ and assurance $\left(F_{2,119}=2.20\right)$. Figures 5 through 7 show that high priced locally-owned service organizations have a much better rating for tangibles, reliability, and assurance respectively, as compared to their low priced counterparts. Interestingly, there is hardly any price effect on the tangibility ratings for foreign-owned restaurant chains or in-hotel restaurants located inside foreign-owned hotels (see Figure 5). For reliability and assurance, price does not have significant influence for in-hotel restaurants. Thus we find partial support for $\mathrm{H} 3$.

\section{Summary of Results}

We found strong support for all three hypotheses. In particular, Hypothesis 1 (i.e., foreignowned services are perceived to be of better quality than locally-owned services) was supported for all service dimensions except tangibles for hotels, and for all service quality dimensions for restaurants. Thus, we found widespread support for Hypothesis 1 for both service categories.

The support for Hypothesis 2 (i.e., price has a positive relationship with the perceived service 
quality for both foreign-owned and locally-owned service organizations) was also widespread because no significant difference was found for any of the five quality dimensions for both services.

Hypothesis 3 (i.e., the influence of price on perceived service quality will be greater for locallyowned service organizations than for foreign-owned service organization) was also supported for several quality ratings for both hotels and restaurants. For example, it was strongly supported for reliability, assurance and empathy for hotels, and tangibles, reliability and assurance for restaurants.

\section{Managerial Implications}

Our study is carried out from the perspective of Chinese consumers. Two service categories, hotels and restaurants, are studied for the sake of generalizability of research findings (Kaynak and Cavusgil 1983). Moreover, the study examines whether the COO effect is diminished when price information is also available. Results indicate a significant $\mathrm{COO}$ effect on the service evaluation of Chinese consumers. Similarly, price level had significantly greater influence on quality evaluation for local hotels and restaurants as compared to their foreign-owned counterparts. In other words, Chinese consumers make a distinction in quality ratings between high and low priced Chinese brands. Thus, the brand managers of high-priced Chinese brands have to do a better job in establishing a "high quality" positioning for their brands. For example, they should concentrate on one or two key attributes (e.g., reliability, assurance, empathy etc.), and then communicate the attributes effectively to the target customers.

It is also found that except for responsiveness, the quality ratings for low-priced American hotels are not significantly different from those of high-priced American hotels (see Figures 1-4). This result indicates that American hotels should not charge a low price for the sake of capturing market share. Chinese consumers have come to expect higher price for American hotels. A deliberately set "low" or "competitive" price for an American hotel chain may send a confusing signal to the 
consumers. Thus, American hotel chains may be better off positioning themselves in terms of value (i.e., good quality at an affordable price) instead of price.

\section{Conclusion}

The COO effect for products has been investigated extensively over the years. There is a broad consensus that products from industrialized nations enjoy positive $\mathrm{COO}$ effect whereas those from the developing countries suffer from negative COO effect. Unfortunately, the literature on COO effect is not as extensive for services as for products. Also, most of these studies are undertaken in the industrialized countries. Hence, neither the empirical findings nor the conceptual frameworks of these studies can be directly extrapolated to the domain of Newly Industrialized Countries (NICs). Our study is one of the first attempts in filling this cross-cultural void in the COO literature for services.

The present study has several limitations. First, the study is carried out only in China. The results may not be directly applied to another country. However, a similar research methodology may be used to examine possible $\mathrm{COO}$ effects in other developing as well as developed countries. Also, a more comprehensive study will include a few more service categories to ensure better generalization of results.

It is expected that the present study will inspire others to investigate the COO effect for services in other national settings. Besides price, other cues such as brand name should also be utilized along with the $\mathrm{COO}$ effect for a thorough examination of this important effect. 


\section{References}

Ahmed Z., Johnson J., Ling C., Fang T., Hui A. (2002), "Country-of-Origin and Brand Effects on Consumers' Evaluations of Cruise Lines,” International Marketing; 19, 2/3, pp. 279.

Ahmed, S.A. \& d'Astous, A. (2007), "Moderating Effect of Nationality on Country-of-origin Perceptions: English-speaking Thailand versus French-speaking Canada," Journal of Business Research, 60(3), 240-8.

Ananth, M., DeMicco, F., Moreo, P. \& Howey, R. (1992), "Marketplace lodging needs of mature travelers," Cornell Hotel \& Restaurant Administration Quarterly. 33(4), 12.

Bandyopadhyay, S., Wongtoda, N. and Rice, G. (2011), "Measuring the Impact of Inter-attitudinal Conflict on Consumer Evaluation of Foreign Products," Journal of Consumer Marketing, 28, 3, 211-224.

Bandyopadhyay, S. and Banerjee, B. (2002), “A Country of Origin Analysis of Foreign Products by Indian Consumers," Journal of International Consumer Marketing, 15 (2), 85-109.

Bandyopadhyay, S. and Dong, C. (1995), "Beyond Country-of-Origin Effects: Introducing the Concept of Place-of-Origin," Proceedings of the 5th International Marketing and Development Conference, Beijing, 39-43.

Bandyopadhyay, S. and Pardasani, M. (2011), "Do Quality Perceptions of Health and Social Services Vary for Different Ethnic Groups? An Empirical Investigation," International Journal of Nonprofit and Voluntary Sector Marketing, 16, 99-114.

Brookshire, J.H. \& Yoon, S.H. (2012), "Country of Origin factors influencing US consumers' perceived price," Journal of Consumer Marketing, pp. 446-450.

Buzzell, R. D. and Gale, B. T. (1987), The PIMS Principles. New York: The Free Press.

Cateora, P. C, Gilly, M. C., \& Graham, J.L. (2012), International Marketing (16 ${ }^{\text {th }}$ ed.), McGraw-Hill.

Chao, P. (1989), "The Impact of Country Affiliation on the Credibility of Product Attribute Claim," Journal of Advertising Research, 29, 2, 35-41.

Chao, P. (1993), "Partitioning Country of Origin Effects: Consumer Evaluations of a Hybrid Product," Journal of International Business Studies, 24, 2, 291-306.

Choi T. Y., \& Chu R. (2001), “Determinants of hotel guests' satisfaction and repeat patronage in Hong Kong hotel industry." International Journal of Hospitality Management, 20: 277-297.

Emmett, D. (2012), "Daily Dose of iQ: Customers' Perceived Wait Time is What Matters," iQmetrix. 
Ettenson, R. \& Klein, J.G. (2005), "The fallout from French nuclear testing in the South Pacific - a longitudinal study of consumer boycotts, “International Marketing Review, 22(2), 199-224.

Gallup (1991), "Reported in Image of U.S. Products Improve Here, Not Abroad,” Wall Street Journal, October, C19.

Hauser, J. R. and D. Clausing (1988), “The House of Quality,” Harvard Business Quality, 66 (May/June), pp. 63-73.

Job Outsourcing Statistics (2014), Statistic Brain, Accessed on 12 Sept. 2014 from web site: http://www.statisticbrain.com/outsourcing-statistics-by-country/.

Jones, P., and M. Dent (1994), "Improving Service: Managing Response Time in Hospitality Operations," International Journal of Operations \& Production Management 14.5, pp. 52-58.

Koska, M. T. (1990), “High Quality \& Hospital Profits: Is there a Link?” Hospitals, 64, pp. 62-63.

Lin, C., Cheryl, C., Rungting, T., Ke, C., and Tu, Pi (2009), “The Changing Expectations of Consumers in Cross-Cultural Service Encounters," International Management Review, 3.3, pp. 32-33.

Javalgi, Rajshekhar G., Cutler, Bob D., and Winans, William A., 2001, "At your service! Does country of origin research apply to services?" Journal of Services Marketing, 15(6/7): 565.

Johansson, J.K., Douglas, S.P. and Nonaka, I. (1985), “Assessing the Impact of Country of Origin on Product Evaluations: a New Methodological Perspective," Journal of Marketing Research, Vol.22, November, pp. 388-96.

Kaynak, E. and Cavusgil, S.T. (1983), "Consumer Attitudes toward Products of Foreign Origin: Do they Vary across Product Classes?” International Journal of Advertising. Vol. 2, No. 2, April/June, pp.147-57.

Kettinger, W. J. and Lee, C. C. (1995), "Perceived Service Quality and User Satisfaction with the Information Services Function.” Decision Sciences, 25, 5-6, pp. 737-766.

Khanna, S.R. (1986), "Asian Companies and the Country Stereotype Paradox: An Empirical Study," Columbia Journal of World Business, Summer, pp. 29-38.

Lawrence, A. (2012), "Five Customer Retention Tips for Entrepreneurs," Forbes Magazine, pp. 1-6.

Maheswaran, D. (1994), "Country of Origin as a Stereotype: Effects of Consumer Expertise and Attribute Strength on Product Evaluations," Journal of Consumer Research, 21, 71-82.

Maister, D. (1985), “The Psychology of Waiting Lines,” in J. A. Czepiel, M. R. Solomon \& C. F. Surprenant (Eds.), The Service Encounter: Managing Employee/Customer Interaction in Service Businesses. Lexington, MA: D. C. Heath and Company, Lexington Books. 
Newswire (2013), "Under the Influence: Consumer Trust in Advertising," Nielsen, Accessed on 12 September 2014 from web site: http://www.nielsen.com/us/en/insights/news/2013/under-theinfluence-consumer-trust-in-advertising.html.

Pardasani, M. and Bandyopadhyay, S. (2014), "Ethnicity Matters: The Expereinces of Minority Groups in Public Health Programs," Journal of Cultural Diversity, 21, 3, 90-98.

Parasuraman, A., V. A. Zeithaml and L. L. Berry (1988), "SERVQUAL: A Multi-item Scale for Measuring Consumer Perceptions of Service Quality," Journal of Retailing, 64, 1, pp. 12-40.

Prabaharan, B., A. Raj, A. and V.Rajagopal, (2008), "Service Quality on Tourism: Application of Structural Equation Modeling," Dspace.iimk.ac.in, pp. 1-6.

Pruden, H. O. (1971), "Which Ethics for Marketers," in John R. Wish and Stephen H. Gamble, Marketing and Social Issues, New York: John Wiley and Sons, Inc.

Rao, S. (2012), "Country of Origin Effect on Global Brands." Citeman Network RSS. Cite CO, 21 Feb. 2012. Web. 05 Sept. 2014.

Swan, J. E. and Johannah Jones Nolan (1985), "Gaining Customer Trust: A Conceptual Guide for the Salesperson,” Journal of Personal Selling and Sales Management, Vol. 5, pp. 39-48.

Thi B. H. \& T. Nguyen, (2012), "Resources for Service Quality Improvement as Competitive Advantages: A Conceptual Model for Services Firms in Vietnam," Journal of Sustainable Development, Vol.5, pp.141-145.

Thorelli, H. B., J.S. Lim and J.Ye (1989), "Relative Importance of Country-of-Origin, Warranty, and Retail Store Image on Product Evaluation,” International Marketing Review, 6(1), 35-46.

Upal, M. (2008), “Telecommunication Service Gap: Call Center Service Quality Perception and Satisfaction," Communications of the IBMIA 3, 18-27.

Wang, C. L., and Chen, Z.X. (2004), "Consumer Ethnocentrism and Willingness to Buy Domestic Products in a Developing Country Setting: Testing Moderating Effects," Journal of Consumer Marketing, 21(6), 391-400.

Webster, C. (1989) "Can Consumers be Segmented on the Basis of their Service Quality Expectations?" Journal of Services Marketing, Vol. 3 Issue: 2, pp. 35 - 53.

Wong, A., Dean, A., White, C. J. (1999), "Analyzing service quality in the hospitality industry", Managing Service Quality: An International Journal, Vol. 9 Issue: 2, pp.136 - 143.

Wongtoda, N., G. Rice, and Bandyopadhyay, S. (2012), "Developing and Validating AFFINITY: A New Scale to Measure Consumer Affinity towards Foreign Countries," Journal of International Consumer Marketing, 24, pp. 147-167. 
Yin Ho, J. S., Lai Teik, D. O., Tiffany, F., Fatt Kok, L., and Yang Teh, T. (2012)," The Moderating Effects of Local VS. Foreign Courier Service Providers on Logistic Service Quality (LSQ)," International Journal of Trade, Economics and Finance, 3 (4), pp.257-261.

Zeithaml, V. A., Berry L. L., and Parasuraman, A. (1996), "The Behavioral Consequences of Service Quality," Journal of Marketing, April, pp. 31-46.

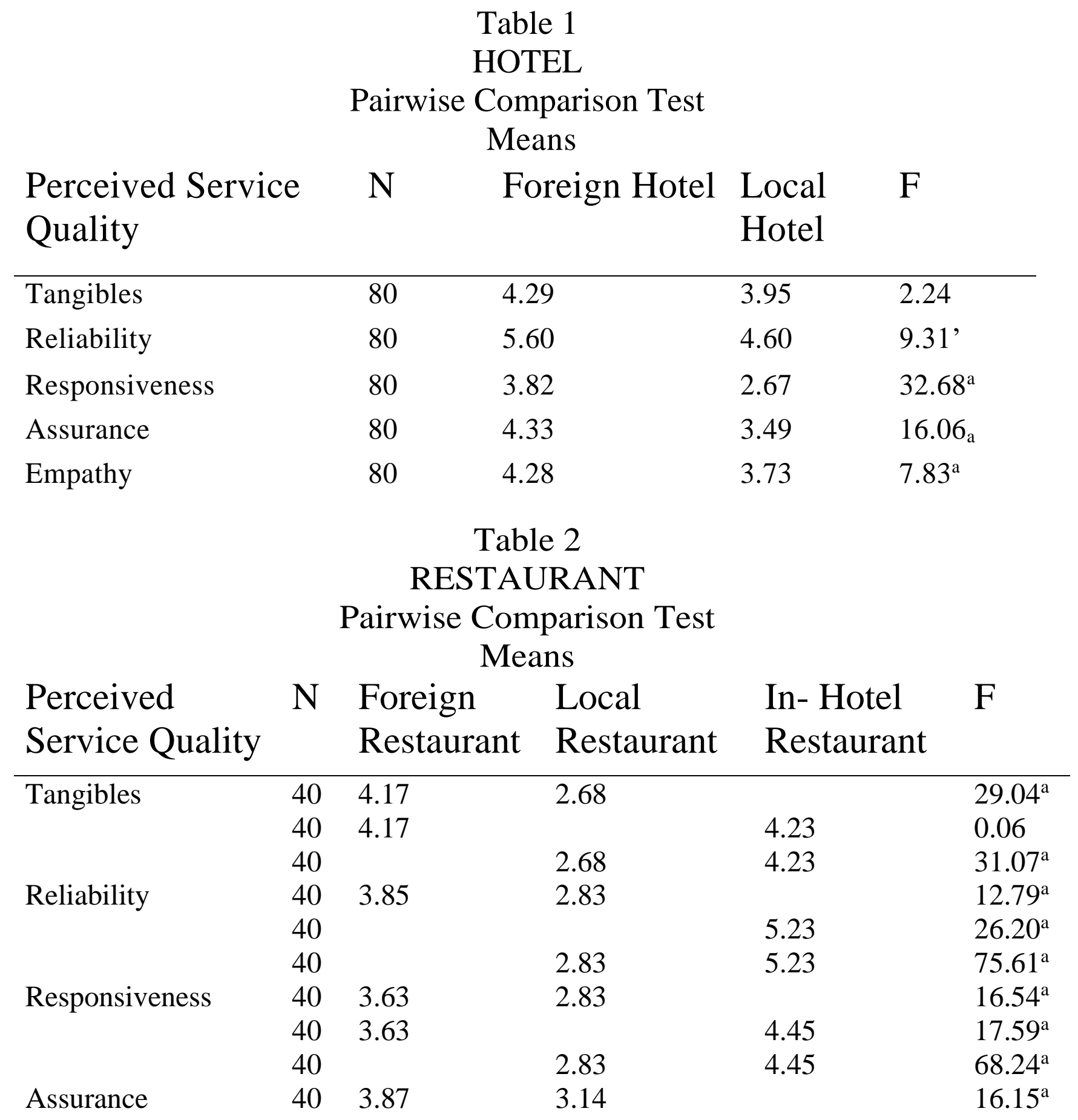




\begin{tabular}{llllll} 
& 40 & 3.87 & & 4.35 & $7.18^{\mathrm{a}}$ \\
Empathy & 40 & & 3.14 & 4.35 & $44.87^{\mathrm{a}}$ \\
& 40 & 3.97 & 2.64 & & $76.48^{\mathrm{a}}$ \\
& 40 & 3.97 & 2.64 & 4.18 & 1.91 \\
40 & & 4.18 & 02.53 \\
\multicolumn{5}{r}{ a: Significant at 0.01 level }
\end{tabular}


Table 3

HOTEL

\section{Analysis of Variance \\ Dependent Variables}

\begin{tabular}{|c|c|c|c|c|c|c|c|c|c|c|c|}
\hline \multirow{2}{*}{$\begin{array}{l}\text { Independent } \\
\text { Variables }\end{array}$} & \multirow[b]{2}{*}{$\underline{\mathrm{DF}}$} & \multicolumn{2}{|c|}{ Tangibles } & \multicolumn{2}{|c|}{ Reliability } & \multicolumn{2}{|c|}{ Responsiveness } & \multicolumn{2}{|c|}{ Assurance } & \multicolumn{2}{|c|}{ Empathy } \\
\hline & & $\underline{S S^{c}}$ & F & $\underline{\mathrm{SS}}$ & F & $\underline{\text { SS }}$ & $\underline{F}$ & $\underline{\text { SS }}$ & $\underline{F}$ & $\underline{S S}$ & $\underline{F}$ \\
\hline Price & 1 & 4.45 & $4.46^{\mathrm{a}}$ & 20.34 & $12.17^{\mathrm{a}}$ & 1.61 & 2.14 & 12.86 & $20.11^{\mathrm{a}}$ & 2.43 & $3.54^{\mathrm{a}}$ \\
\hline $\mathrm{COO}$ & 1 & 3.47 & $3.48^{\mathrm{a}}$ & 9.76 & $5.84^{\mathrm{a}}$ & 17.80 & $26.39^{\mathrm{a}}$ & 10.92 & $17.08^{\mathrm{a}}$ & 3.00 & $4.37^{\mathrm{a}}$ \\
\hline Price X $\mathrm{COO}$ & 1 & 1.45 & 1.45 & 15.76 & $9.43^{\mathrm{a}}$ & 3.98 & $5.31^{\mathrm{a}}$ & 8.41 & $13.15^{\mathrm{a}}$ & 3.68 & $5.37^{\mathrm{a}}$ \\
\hline $\begin{array}{l}\text { Duration of } \\
\text { stay }\end{array}$ & 1 & 0.17 & 0.17 & 0.32 & 0.19 & 2.58 & $3.44^{\mathrm{b}}$ & 1.91 & $2.99^{\mathrm{a}}$ & 0.17 & 0.25 \\
\hline $\begin{array}{l}\text { a: Signif } \\
\text { b: Signif } \\
\text { c: Sum s }\end{array}$ & at 0 & $\begin{array}{l}\text { level } \\
\text { level }\end{array}$ & & & & & & & & & \\
\hline
\end{tabular}

Table 4

\section{RESTAURANT}

Analysis of Variance
Dependent Variables

\begin{tabular}{|c|c|c|c|c|c|c|c|c|c|c|c|}
\hline \multirow{2}{*}{$\begin{array}{l}\text { Independent } \\
\text { Variables }\end{array}$} & \multirow[b]{2}{*}{$\underline{\mathrm{DF}}$} & \multicolumn{2}{|c|}{ Tangibles } & \multicolumn{2}{|c|}{ Reliability } & \multicolumn{2}{|c|}{ Responsiveness } & \multicolumn{2}{|c|}{ Assurance } & \multicolumn{2}{|c|}{ Empathy } \\
\hline & & SS & $\underline{F}$ & $\underline{\mathrm{SS}}$ & $\underline{F}$ & SS & $\underline{F}$ & SS & $\underline{F}$ & $\underline{S S}$ & F \\
\hline Price & 1 & 9.73 & $7.03^{\mathrm{a}}$ & 14.84 & $11.72^{\mathrm{a}}$ & 0.02 & 0.02 & 7.16 & $12.24^{\mathrm{a}}$ & 0.09 & 0.18 \\
\hline $\mathrm{COO}$ & 2 & 55.01 & $19.86^{\mathrm{a}}$ & 104.03 & $41.08^{\mathrm{a}}$ & 46.21 & $29.64^{\mathrm{a}}$ & 28.26 & $24.16^{\mathrm{a}}$ & 53.80 & $5.70^{\mathrm{a}}$ \\
\hline Price $\mathrm{X} \mathrm{COO}$ & 2 & 14.74 & $5.32^{\mathrm{a}}$ & 7.02 & $2.85^{\mathrm{b}}$ & 0.01 & 0.01 & 2.58 & $2.20^{\mathrm{b}}$ & 0.16 & 0.17 \\
\hline
\end{tabular}


Figure 1

\section{Hotel}

Interaction between Price and $\mathrm{COO}$

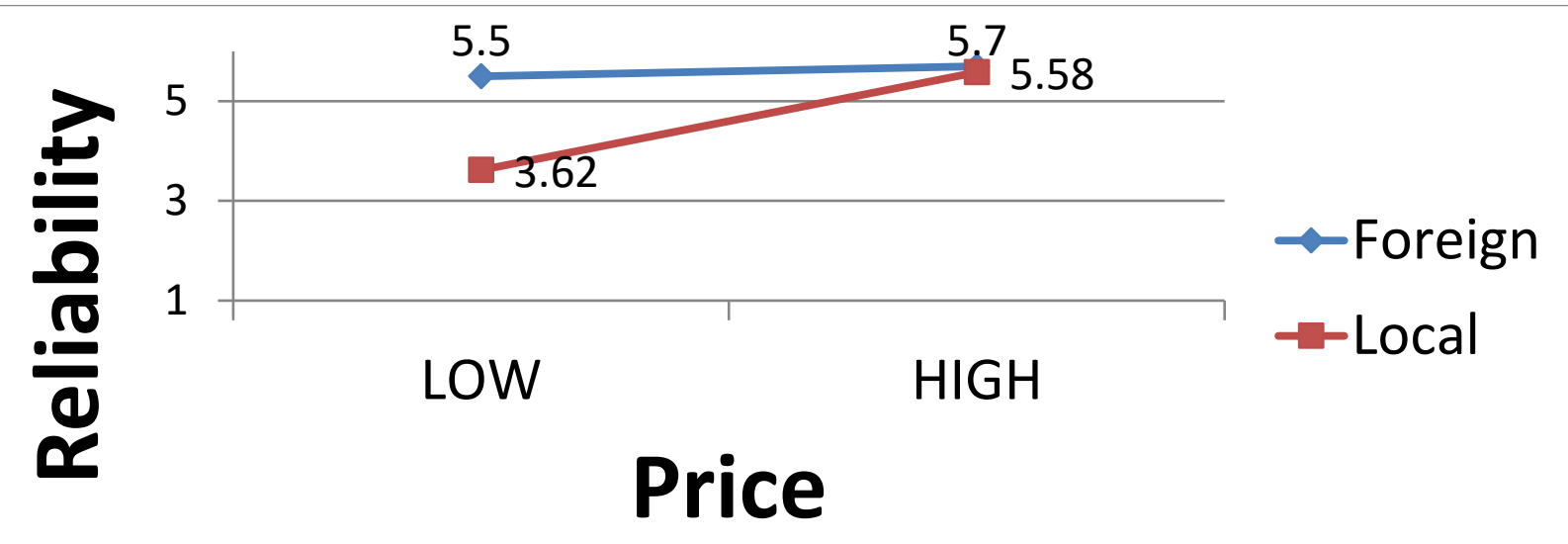

Figure 2

Hotel

Interaction between Price and COO

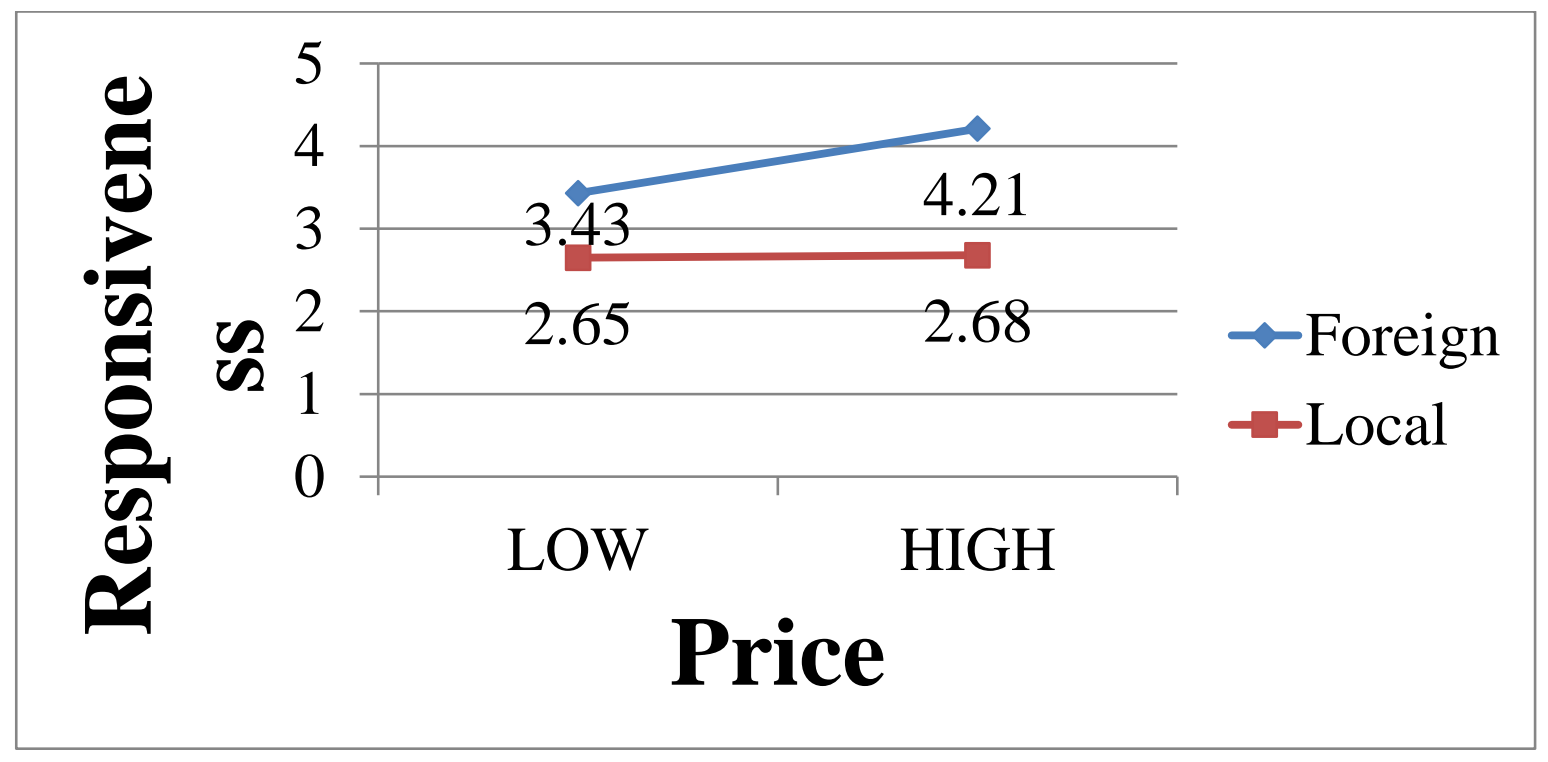




\section{Figure 3}

Hotel

Interaction between Price and COO

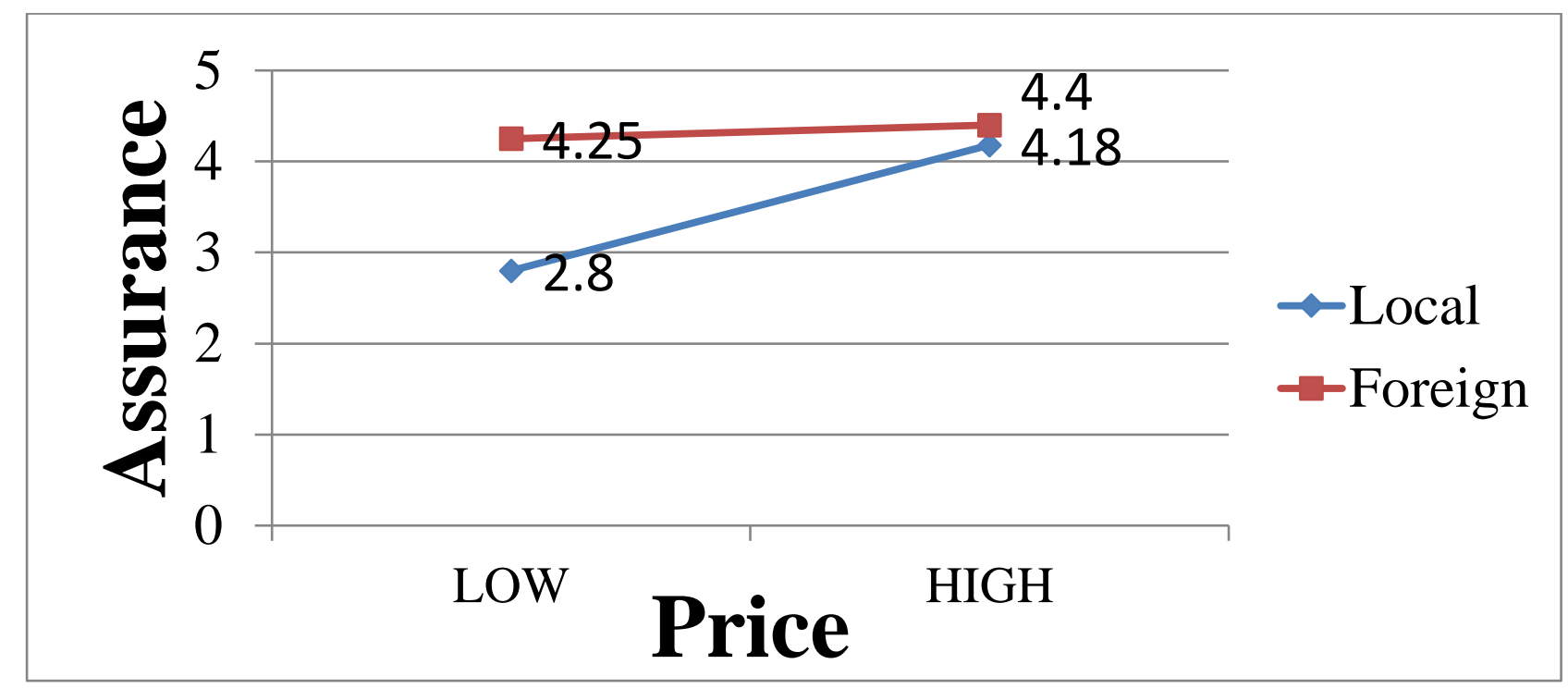

Figure 4

Hotel

Interaction between Price \& COO

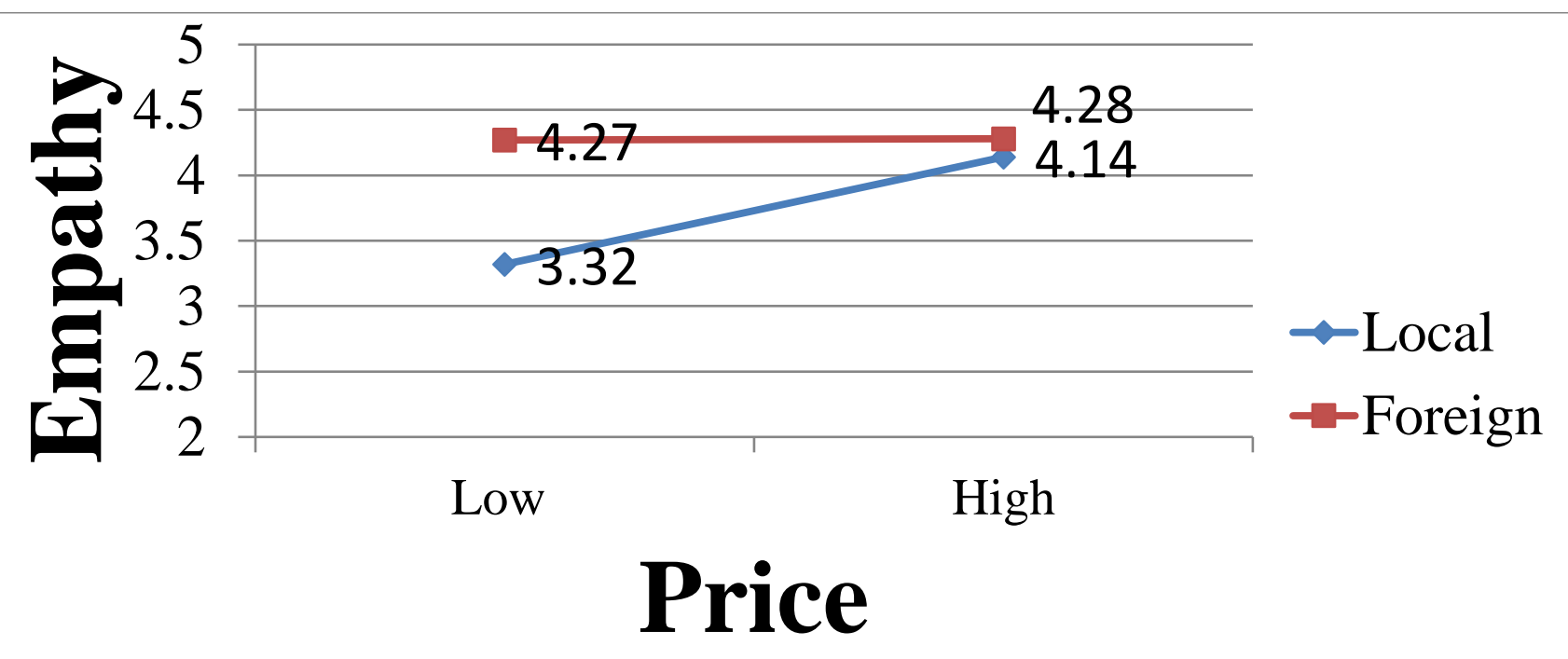




\section{Figure 5}

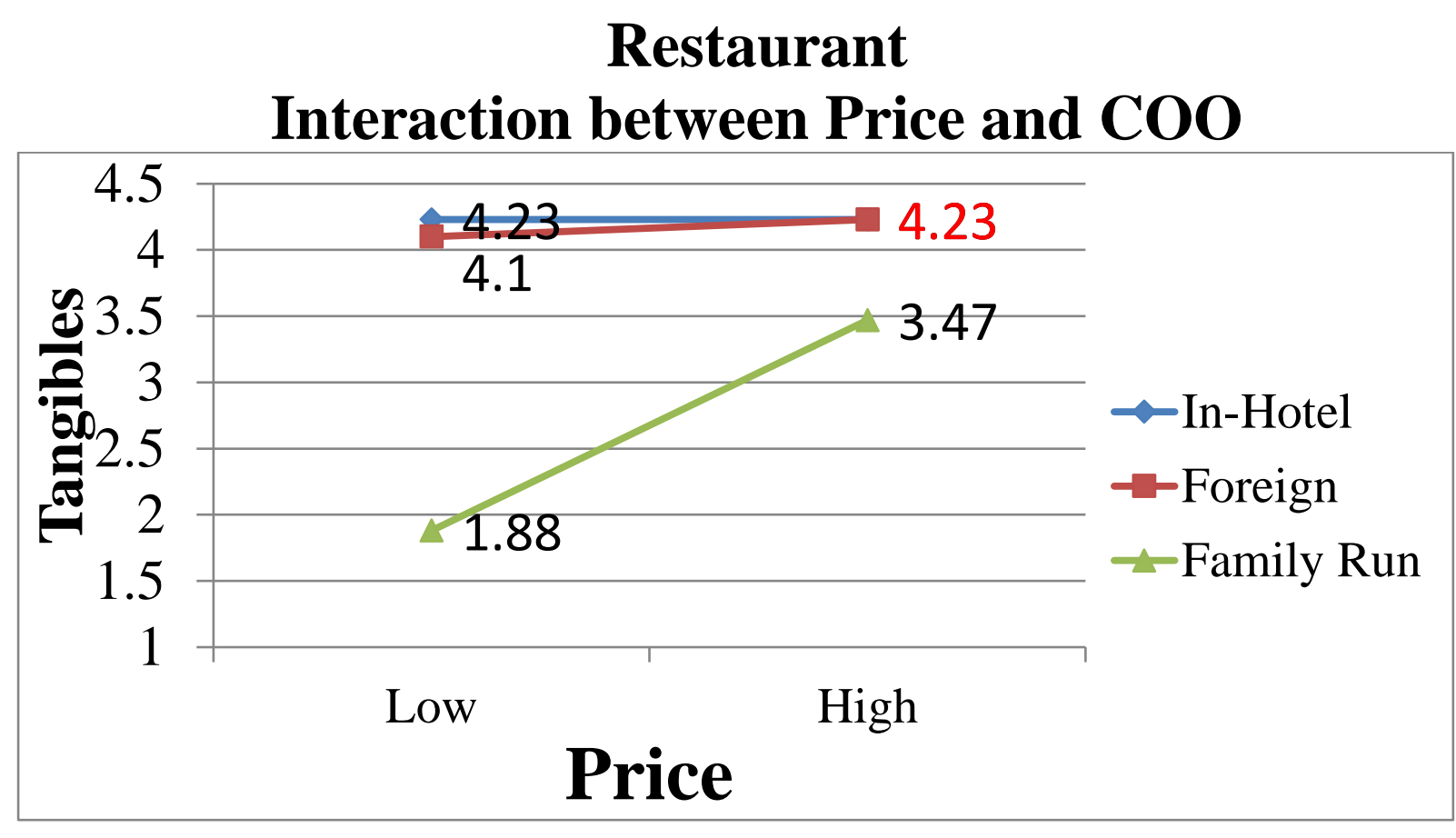

Figure 6

Restaurant

Interaction between Price and COO

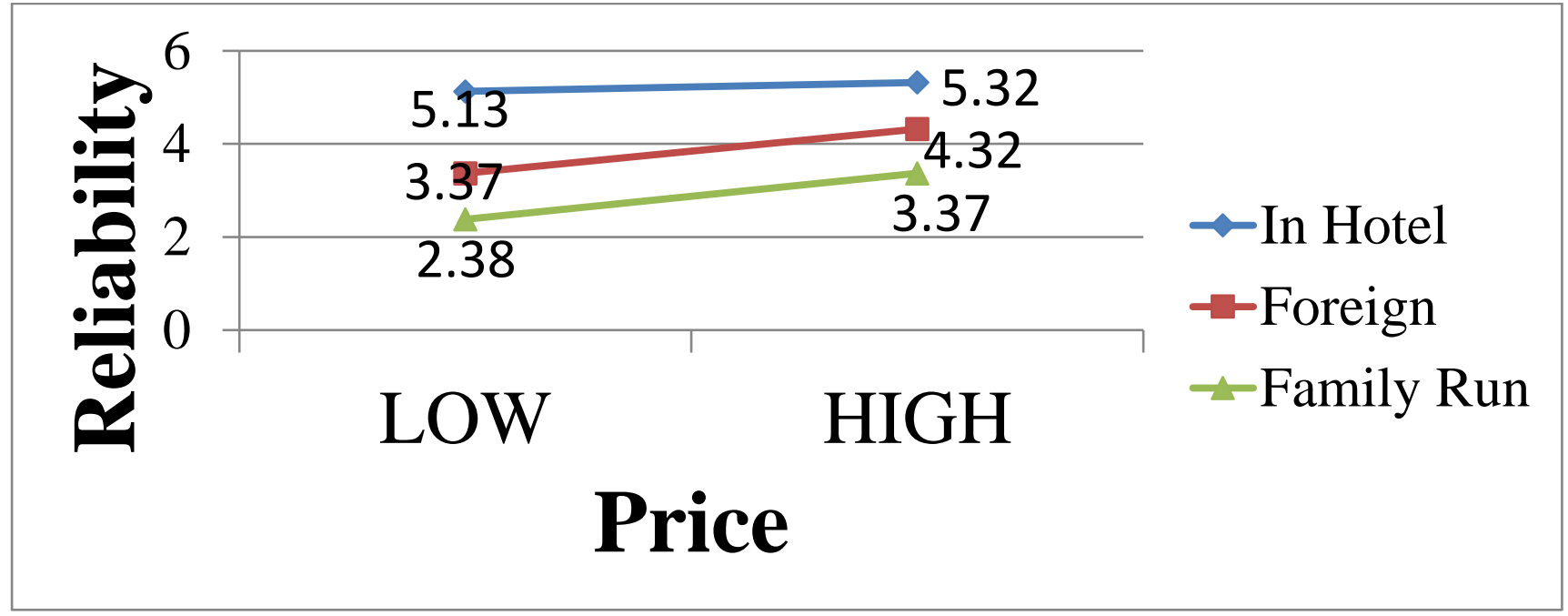




\section{Figure 7 \\ Restaurant \\ Interaction between Price and COO}

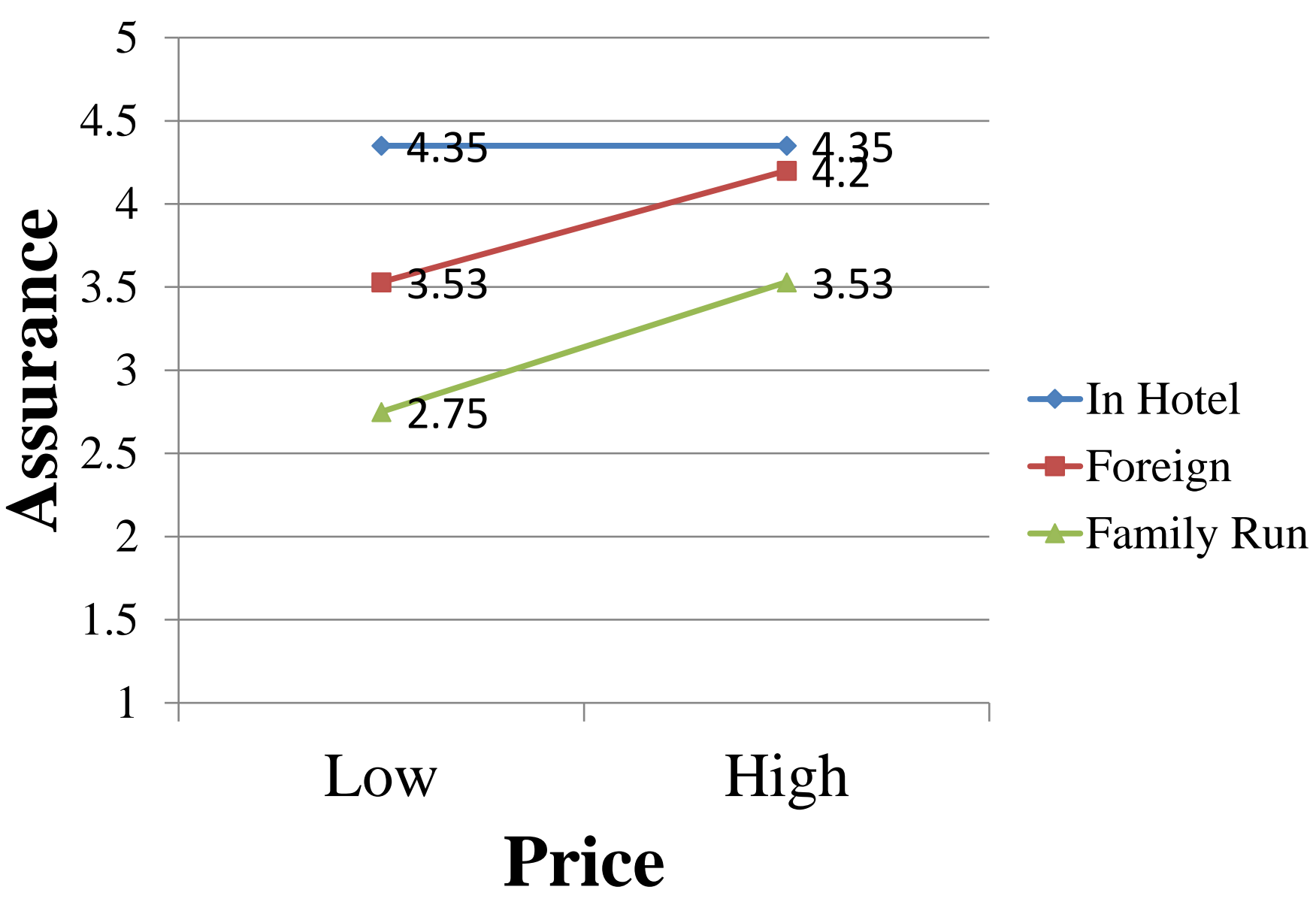

